\title{
Pharmacokinetics of Tylvalosin in Broiler Turkeys (Meleagris Gallopavo) After Single Intravenous and Oral Administration
}

\author{
Mohamed Elbadawy ${ }^{1 \star t}$, Mohamed Aboubakr ${ }^{1 \dagger}$ and Amira Abugomaa ${ }^{2 \dagger}$ \\ ${ }^{1}$ Department of Pharmacology, Faculty of Veterinary Medicine, Benha University, Moshtohor, Egypt, ${ }^{2}$ Faculty of Veterinary \\ Medicine, Mansoura University, Mansoura, Egypt
}

OPEN ACCESS

Edited by:

Nora Mestorino,

National University of La

Plata, Argentina

Reviewed by:

Hector Sumano,

National Autonomous University of Mexico (UNAM), Mexico

Lilia Gutierrez,

National Autonomous University of Mexico (UNAM), Mexico

*Correspondence:

Mohamed Elbadawy mohamed.elbadawy@fvtm.bu.edu.eg

TORCID:

Mohamed Elbadawy orcid.org/0000-0001-9368-1535

Mohamed Aboubak orcid.org/0000-0003-1719-4844

Amira Abugomaa

orcid.org/0000-0002-8259-8258

Specialty section: This article was submitted to Veterinary Pharmacology and

Toxicology,

a section of the journa

Frontiers in Veterinary Science

Received: 17 August 2019 Accepted: 27 September 2019

Published: 17 October 2019

Citation:

Elbadawy $M$, Aboubakr $M$ and Abugomaa A (2019) Pharmacokinetics

of Tylvalosin in Broiler Turkeys

(Meleagris Gallopavo) After Single Intravenous and Oral Administration.

Front. Vet. Sci. 6:355

doi: 10.3389/fvets.2019.00355
Pharmacokinetics of tylvalosin (TVN) were determined in eight broiler turkeys following a single intravenous (IV) and peroral (PO) administration of $25 \mathrm{mg} / \mathrm{kg}$ b.w using a crossover design with a 3 weeks washout period. Blood samples were taken between 0.083 and $24 \mathrm{~h}$ following TVN administration, plasma was separated and assayed for TVN concentrations by HPLC. The non-compartmental analysis was used to analyze plasma concentration-time curves. After IV administration, the pharmacokinetic profile was best described by a two-compartment model. The mean distribution and elimination half-lives were 0.382 and $5.71 \mathrm{~h}$, respectively. The distribution volume at steady state, total body clearance and mean residence time were $8.30 \mathrm{~L} / \mathrm{kg}, 1.17 \mathrm{~L} / \mathrm{h}$, and $7.16 \mathrm{~h}$, respectively. After administering orally, the mean absorption half-life and absorption time of TVN was 0.955 and $2.31 \mathrm{~h}$, respectively. The peak plasma concentration was $1.08 \mu \mathrm{g} / \mathrm{mL}$ and achieved at $2.0 \mathrm{~h}$ post-administration and the bioavailability was 53.3\%. The plasma protein binding percent was 13\%. For a successful clinical efficacy of TVN in broiler turkeys, a dosage regimen of $25 \mathrm{mg} / \mathrm{kg}$ b.w, given orally each day is recommended to keep efficient plasma levels above the MIC for most susceptible microorganisms.

Keywords: bioavailability, macrolides, pharmacokinetics, tylvalosin, broilers, turkeys

\section{INTRODUCTION}

Bacterial infections can endanger the lives of human beings and livestock or cause serious economic losses; therefore, antibacterial intervention is a critical issue. However, due to the frequent use of classical antibiotics, developing resistant bacterial strains continues to be a constant medical problem. New antibacterial agents can solve such an issue.

Tylvalosin is a new, broad-spectrum, third-generation veterinary macrolide antibiotic with 16-membered lactone ring and obtained from tylosin by the change of 3-acetyl-40isovaleryl group to be acetylisovaleryltylosin tartrate $(1,2)$. As a macrolide, TVN inhibits the synthesis of bacterial protein by irreversible binding to $50 \mathrm{~S}$ ribosome subunit of susceptible bacteria. Tylvalosin possesses a wide range of biological activities and significant therapeutic uses $(3,4)$. Against Mycoplasma species, TVN is extremely effective in vitro (5), and also against some isolates of Brachyspira pilosicoli, Brachyspira hyodysenteriae, and some anaerobes like Clostridium and Bacteroides species (6). Tylvalosin is used in swine for treating porcine proliferative enteritis, swine enzootic pneumonia and swine dysentery (1), and in poultry to control respiratory (Mycoplasma Species and Ornithobacterium rhinotracheale) and enteric (Clostridium perfringens) bacterial infections $(6,7)$. Moreover, TVN 
is better than tylosin in the higher intracellular penetration and accumulation inside respiratory and gut epithelial cells as well as phagocytic cells (3). Furthermore, TVN was shown to exhibit anti-inflammatory like characteristics and alleviates acute lung damage (2). Such data could suggest a substantially improved effect of TVN vs. tylosin. These features make TVN an attractive and prospective alternative against violent susceptible bacteria in the veterinary field. The safety and efficacy of macrolide antibiotics could be interpreted using their pharmacokinetic and pharmacodynamic data especially the cumulative time that the concentration exceeds the MIC (\% T > $\mathrm{MIC}$ ) for the time-dependent macrolides and $\mathrm{AUC}_{24 \mathrm{~h}} / \mathrm{MIC}$ for the concentration-dependent ones, as azithromycin. However, there are few available data on avian pharmacotherapy and the shortage of pharmacokinetic data impedes the rational use of TVN in targeted avian species. Therefore, the current study was performed to characterize the disposition profile of TVN in broiler turkeys after single oral and intravenous administration.

\section{MATERIALS AND METHODS}

\section{Drug and Chemicals}

Tylvalosin (Aivlosin ${ }^{\circledR}$ ) was obtained as $62.5 \%$ water-soluble white granules (ECO Animal Health, London, UK). Each gram powder contains $625 \mathrm{mg}$ of TVN as TVN tartrate. The internal standard, roxithromycin was obtained from SigmaAldrich Corp. (St. Louis, U.S.A.). Other chemicals and reagents consumed in the current study were acquired commercially and of HPLC grade.

\section{Experimental Turkeys}

Eight clinically healthy broiler black turkeys (Meleagris gallopavo, 4 males and 4 females), weighing between 5.2 and $6.5 \mathrm{~kg}$ and of 11 weeks age were obtained from a local commercial turkeys farm and utilized to determine the pharmacokinetics of TVN. Turkeys were fed on a balanced ration free from drugs and water was supplemented ad libitum. Turkeys were housed in a hygienic room at $22 \pm 1{ }^{\circ} \mathrm{C}$ and $60 \pm 10 \%$ humidity with a light cycle of $12 \mathrm{~h} /$ day for 2 weeks before being used to acclimatize the environment and for ensuring complete clearance of any antibacterial agents. All turkeys were clinically healthy before drug administration. The experimental protocol was approved ethically by the local Ethical Committee of the Faculty of Veterinary Medicine, Benha University, Egypt.

\section{Drug Administration and Blood Sampling}

Before TVN administration, each bird was weighed to determine its dose. A Crossover design with a 3 weeks washout interval between the two routes of administration was used. Turkeys were divided into two groups $(n=4)$ and TVN was given as a single dose at $25 \mathrm{mg} / \mathrm{kg}$ b.w. (according to the manufacturer instructions) orally (intra-crop using oral gavages) and intravenously into the right brachial vein. Using the left brachial vein, blood samples ( $1 \mathrm{~mL}$ each) were obtained before and $0.083,0.167,0.25,0.5,1,2,4,6,8,12$, and 24 h post-drug administration using Venflon IV cannula and centrifuged at
$1,600 \mathrm{~g}$ for $10 \mathrm{~min}$. Plasma was aspirated and stored at $-20^{\circ} \mathrm{C}$ until analyzed.

\section{Analytical Method}

Tylvalosin concentrations in turkey's plasma were assayed by HPLC as described before (8) with some modifications. Briefly, roxithromycin (as an internal standard) was mixed with every standard, quality control sample and plasma sample at a level of $1 \mu \mathrm{g} / \mathrm{mL}$. The plasma samples were mixed with $400 \mu \mathrm{L}$ of acetonitrile including formic acid $(0.1 \%)$, vortexed for $10 \mathrm{~s}$ and centrifuged at 20,000 $\mathrm{g}$ for $10 \mathrm{~min}$ at $4^{\circ} \mathrm{C}$. Subsequently, the supernatant was gathered and evaporated to dryness in a thermostatically controlled water-bath maintained at $35^{\circ} \mathrm{C}$ (Rotavapor ${ }^{\circledR}$ R-114, Shibata Company, Tokyo, Japan). The residue was reconstituted in $150 \mu \mathrm{L}$ mobile phase and defatted with $400 \mu \mathrm{L}$ hexane, and the aqueous layer was collected and filtered by a $0.45 \mu \mathrm{m}$ HPLC filter (Chromatodisc ${ }^{\circledR}$, Kurabo Biomedical Company, Osaka, Japan) and $50 \mu \mathrm{L}$ of the filtrate were injected into the HPLC column.

The HPLC system (Shimadzu Corporation, Kyoto, Japan) composed of a UV detector (SPD-6A), an integrator (Chromatopac C-R7A plus), a pump (LC-10AD) and a loop injector (Model 7125). The mobile phase consists of acetonitrile and $(0.15 \mathrm{M})$ ammonium acetate buffer (49:51, v/v) solution. The analytical separation was accomplished by using Agilent TC-C18 column $(5 \mu \mathrm{m}, 4.6 \times 250 \mathrm{~mm}$, Agilent Technologies, USA) at $25^{\circ} \mathrm{C}$. The flow rate was adjusted at $1 \mathrm{~mL}$ per min and the wavelength of the detector was $289 \mathrm{~nm}$.

The calibration was carried out by spiking of $20 \mu \mathrm{L}$ of diluted TVN standard solutions ranging between 0.019 and $20 \mu \mathrm{g} / \mathrm{mL}$ into $500 \mu \mathrm{L}$ of blank turkey's plasma and assayed as mentioned above. The result showed that standard calibration curves of TVN were linear $(r=0.995)$. The limit of detection (LOD) was $0.039 \mu \mathrm{g} / \mathrm{mL}$ while limit of quantitation (LOQ) was $0.1 \mu \mathrm{g} / \mathrm{mL}$. The average plasma recovery rate of TVN was $87.2 \%$. The intraand inter-day CV values ranged from 4.28 to $4.92 \%$ and 4.86 to $5.42 \%$, respectively ( $n=5,3$ times, 3 days).

\section{The Extent of Plasma Protein Binding of TVN}

The plasma protein binding capacity of TVN was estimated in vitro by the ultrafiltration method as described previously (9). Different standards of TVN concentrations (as in standard calibration curves of TVN) were prepared, spiked to blank turkey's blank plasma samples in a triplicate manner for each concentration and vortexed for $20 \mathrm{~s}$. Subsequently, samples were kept for $30 \mathrm{~min}$ at $37^{\circ} \mathrm{C}$ to allow binding between plasma protein and TVN. Thereafter, $1 \mathrm{~mL}$ of the sample was loaded into the sample reservoir of Ultrafree ${ }^{\circledR}$ centrifugal filter (UFC30LH00, a low-binding hydrophilic PTFE membrane, Millipore Corporation, Japan) with a pore diameter of $0.45 \mu \mathrm{m}$ and subjected to ultrafiltration by centrifugation at $2,500 \mathrm{~g}$ at $37^{\circ} \mathrm{C}$ for up to $30 \mathrm{~min}$ or until the required volume of ultrafiltrate was obtained. The ultrafiltrate was assayed for TVN concentration as mentioned before. The extent of plasma protein 
binding was estimated with reference to the initial sample concentration according to following Equation;

$$
\begin{aligned}
& \text { Plasma protein binding (\%) } \\
& =\left[\frac{\text { spiked concentration }- \text { ultrafiltrate concentration }}{\text { spiked concentration }}\right] \times 100
\end{aligned}
$$

\section{Assay of TVN Pharmacokinetic Profile}

Following IV injection, the plasma concentration vs. time curves of TVN fit well with the two-compartment model, while after PO administration it fit well with the one-compartment model. Thus, the curves recorded post IV $\left[\mathrm{CP}_{\mathrm{IV}}(t)\right]$ and $\mathrm{PO}$ administration $\left[\mathrm{CP}_{\mathrm{PO}}(t)\right]$ were characterized by Equations (2) and (3), respectively.

$$
\begin{gathered}
\mathrm{CP}_{\mathrm{IV}}(t)=\frac{\text { Dose }}{\mathrm{V}}\left\{\frac{\alpha-\mathrm{k}_{21}}{\alpha-\beta} \cdot \mathrm{e}^{-\alpha \cdot \mathrm{t}}+\frac{\mathrm{k}_{21-\beta}}{\alpha-\beta} \cdot \mathrm{e}^{-\beta \cdot \mathrm{t}}\right\} \\
\mathrm{CP}_{\mathrm{PO}}(t)=\frac{\text { Dose } \cdot \mathrm{F} \cdot k a}{\mathrm{~V}}\left\{\begin{array}{l}
\frac{\mathrm{k}_{21-\alpha}}{(\mathrm{ka}-\alpha)(\beta-\alpha)} \cdot \mathrm{e}^{-\alpha \cdot \mathrm{t}} \\
+\frac{\mathrm{k}_{21}-\beta}{(\mathrm{ka}-\beta)(\alpha-\beta)} \cdot \mathrm{e}^{-\beta \cdot \mathrm{t}} \\
+\frac{\mathrm{k}_{21}-\mathrm{ka}}{(\alpha-\mathrm{ka})(\beta-\mathrm{ka})} \cdot \mathrm{e}^{-\mathrm{ka} \cdot \mathrm{t}}
\end{array}\right\}
\end{gathered}
$$

Equations (2) and (3) were simultaneously fit (10-12) to the plasma concentration vs. time curve of TVN after IV and PO administration into the same turkey, respectively, to determine pharmacokinetic variables by the non-linear least square way using MULTI, a curve fitting program (13).

Several parameters have been calculated using a noncompartmental method of analysis (14). The AUC and AUMC were calculated by the trapezoidal method. The terminal elimination rate constant was estimated using four data points in the terminal part of the concentration vs. time curve by using the non-linear least-square iterative approach. The elimination half-life $\left(t_{1 / 2 \beta}\right)$ was calculated as $t_{1 / 2 \beta}=0.693 / \beta$, where $\beta$ is the elimination rate constant. MRT $=\mathrm{AUMC} / \mathrm{AUC}$ and $\mathrm{Cl}_{\text {tot }}=$ Dose/AUC $\mathrm{A}_{0-\infty}$. The absolute oral bioavailability $(\mathrm{F})=$ $\mathrm{AUC}_{\mathrm{PO}} / \mathrm{AUC}_{\mathrm{IV}} \times 100$ and $\mathrm{MAT}=\mathrm{MRT}_{\mathrm{PO}}-\mathrm{MRT}_{\mathrm{IV}}$. Distribution volume at a steady state $\left(\mathrm{V}_{\mathrm{dss}}\right)=\mathrm{Cl}_{\mathrm{t}} / \mathrm{MRT}_{\mathrm{IV}}$.

\section{RESULTS}

The mean plasma concentration vs. time profile of TVN following a single IV and PO administration of $25 \mathrm{mg} / \mathrm{kg}$ b.w. to broiler turkeys were graphed in Figure $\mathbf{1}$ and there was a good fitting between the observed points and theoretical curves. The pharmacokinetics data (Mean $\pm \mathrm{SE}$ ) estimated from the curve fitting and non-compartmental analysis were shown in Table $\mathbf{1 .}$ Following the IV injection, TVN concentration was sloped in a biphasic manner with a rapid and wide distribution and a long elimination half-life. After PO giving, TVN was quickly absorbed followed by slow elimination. The $\mathrm{C}_{\max }$ was $1.08 \mu \mathrm{g} / \mathrm{mL}$, reached (Tmax) at $2.0 \mathrm{~h}$. The oral bioavailability of TVN was $53.3 \%$. The in vitro plasma protein binding tendency of TVN was low (13 $\pm 0.785 \%)$.

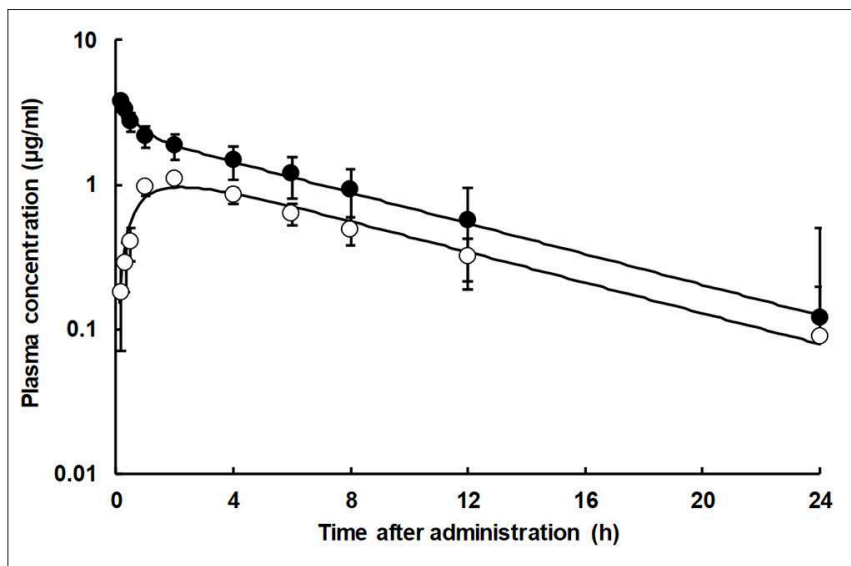

FIGURE 1 | Semi-Logarithmic plot showing the plasma concentration vs. time curve of TVN in broiler turkeys following a single dose of $25 \mathrm{mg} / \mathrm{kg}$ b.w. administered intravenously $(\bullet)$ and orally (o). Each mean \pm SE $(n=8)$ are represented by each point and vertical bar, respectively. The IV and PO theoretical lines were depicted by Equations (2) or (3), respectively, using pharmacokinetic parameters in Table $\mathbf{1 .}$

\section{DISCUSSION}

Disposition of 16-membered lactone ring macrolides has been studied in a lot of avian species, and inter-species variations have been demonstrated as for tylosin in pigeons, quail, emus, and cranes (15) and chickens (16-18) as well as for tilmicosin in chicken (19) and turkeys (20). Tylvalosin itself in chickens during a pilot study showed different absorption profiles in between and within individuals when used on separate occasions (5). These differences in the disposition of macrolides among avian species require thorough pre-clinical assessment.

After IV injection of TVN in turkeys, the plasma concentration vs. time curve was tilted in a biphasic pattern, indicating that the disposition profile of TVN obeyed a twocompartment model. Similar data were recently recorded for TVN in turkey (21) and broiler chickens (22-24) and also for tylosin $(18,25,26)$ and clarithromycin (27) in broiler chickens. Tylvalosin has good distribution profile in turkey as evidenced by a short $(0.382 \mathrm{~h})$ distribution half-life, probably due to extensive tissues distribution. Similarly, a short $(0.076 \mathrm{~h}) \mathrm{t}_{1 / 2 \alpha}$ of TVN in turkeys was recorded (21). Tylvalosin also showed a shorter $\mathrm{t}_{1 / 2 \alpha}(0.153 \mathrm{~h})$ in broiler chickens at the same dose level (24) and after $10 \mathrm{mg} / \mathrm{kg}$ b.w. in laying hens [0.12 h (22)]. Similarly to TVN, the $t_{1 / 2 \alpha}$ of tylosin tartrate (a chemically similar macrolide with time-dependent property) in broiler chickens after IV injection of $50 \mathrm{mg} / \mathrm{kg}$ b.w. was $0.385 \mathrm{~h}$ (25). Contrarily, shorter distribution half-lives were recorded for tylosin phosphate $(0.07 \mathrm{~h})$ and tylosin tartrate $(0.09 \mathrm{~h})$ in chickens but after IV administration of $10 \mathrm{mg} / \mathrm{kg}$ b.w. (18). In the present study, $\mathrm{V}_{\mathrm{dss}}$ for TVN was $8.30 \mathrm{~L} / \mathrm{kg}$ proposing a wide distribution of the drug in tissues of turkeys following IV injection. Similarly, the $\mathrm{V}_{\mathrm{dss}}$ of $\mathrm{TVN}$ in broiler chickens was large $(8.74 \mathrm{~L} / \mathrm{kg})$ after IV administration of the same dose (24). These are greater than those for tylosin reported earlier in broiler chickens as it was 0.69 
TABLE 1 | Mean ( \pm SD, $n=8$ ) plasma pharmacokinetic variables of tylvalosin in broiler turkeys determined following a single dose of $25 \mathrm{mg} / \mathrm{kg}$ b.w. administered intravenously (IV) and orally (PO).

\begin{tabular}{|c|c|c|}
\hline Parameter & IV & PO \\
\hline $\mathrm{k}_{\mathrm{a}}\left(\mathrm{h}^{-1}\right)$ & - & $0.745 \pm 0.146$ \\
\hline $\mathrm{C}_{\max }(\mu \mathrm{g} / \mathrm{mL})$ & - & $1.08 \pm 0.117$ \\
\hline $\mathrm{T}_{\max }(\mathrm{h})$ & - & $2.00 \pm 0.00$ \\
\hline $\mathrm{CP}_{0}(\mu \mathrm{g} / \mathrm{mL})$ & $4.161 \pm 0.688$ & - \\
\hline$\alpha\left(\mathrm{h}^{-1}\right)$ & $1.87 \pm 0.393$ & - \\
\hline$\beta\left(\mathrm{h}^{-1}\right)$ & $0.122 \pm 0.011$ & - \\
\hline $\mathrm{t}_{1 / 2 \mathrm{ka}}(\mathrm{h})$ & - & $0.955 \pm 0.148$ \\
\hline $\mathrm{t}_{1 / 2 \alpha}(\mathrm{h})$ & $0.382 \pm 0.0826$ & - \\
\hline$t_{1 / 2 \beta}(h)$ & $5.71 \pm 0.530$ & - \\
\hline AUC $(\mu \mathrm{g} \cdot \mathrm{h} / \mathrm{mL})$ & $22.1 \pm 4.19$ & $11.7 \pm 2.95$ \\
\hline AUMC $(\mu \mathrm{g} \cdot \mathrm{h} / \mathrm{mL})$ & $159.4 \pm 36.9$ & $112.8 \pm 38.9$ \\
\hline $\mathrm{Cl}_{\mathrm{t}}(\mathrm{L} / \mathrm{h} / \mathrm{kg})$ & $1.17 \pm 0.232$ & - \\
\hline $\mathrm{F}(\%)$ & - & $53.3 \pm 10.8$ \\
\hline MRT (h) & $7.16 \pm 0.398$ & $9.47 \pm 1.06$ \\
\hline $\mathrm{V}_{\text {dss }}(\llcorner/ \mathrm{kg})$ & $8.30 \pm 1.23$ & - \\
\hline MAT (h) & - & $2.31 \pm 0.83$ \\
\hline
\end{tabular}

$k_{a}$, absorption rate constant; $C_{\max }$, maximum plasma level; $T_{\max }$, time to achieve maximum plasma level; $\mathrm{CP}_{0}$, plasma concentration at time zero after IV injection calculated from dose/ $\mathrm{Vd} ; \alpha$ and $\beta$, rate constants representing the slope of distribution phase and elimination phase, respectively; $t_{1 / 2} k a, t_{1 / 2 \alpha}$, and $t_{1 / 2 \beta}$, half-lives of absorption phase, distribution phase and elimination phase, respectively; $A \cup C$, area under the plasma concentration vs. time curve; $A U M C$, area under moment curve; $\mathrm{Cl}_{\text {t }}$, total clearance; $\mathrm{F}$, fraction of drug absorbed systemically after oral administration; MRT, mean residence time; $V_{d s s}$, steady-state volume of distribution; MAT, meantime of absorption.

L/kg (16), 0.94-1.09 L/kg (18), $5.30 \mathrm{~L} / \mathrm{kg}$ (25), and 6.73 L/kg (26) after IV administration. This pharmacokinetic behavior is not surprising since macrolides are weak basic and highly lipophilic drugs with pKa values from 7.1 to 8.9 (pKa of TVN is 7.6) and low plasma protein binding tendency, thus these antibiotics move easily by non-ionic passive diffusion into tissues especially with a lower $\mathrm{pH}$ than blood $(20,21,28)$. In the current study, the in vitro plasma protein binding tendency of TVN was low $(13 \%)$ as is the case with other macrolides (18-30\%) in most species (29). Similarly, tylosin (pKa 7.1) has a low ionization degree and a low binding to serum proteins (40\%) is distributed widely in the body and attains greater tissue concentration than plasma levels (30). Our results showed a long $(5.71 \mathrm{~h})$ elimination half-life $\left(t_{1 / 2 \beta}\right)$ of TVN in broiler turkeys after IV administration which is nearly similar to that of broiler chickens [6.67 h, (24)]. Contrarily, TVN showed short $t_{1 / 2 \beta}(0.788$ and $0.61 \mathrm{~h}$ ) in turkeys and laying hens after IV administration (21) and (22), respectively. The $t_{1 / 2 \beta}$ of tylosin in broiler chickens was also long [5.62 h (26) and 7.29h (27)]. Contrarily, a short $\mathrm{t}_{1 / 2 \beta}$ of tylosin [0.52 h (16) and 1.04-1.16h (18)] was recorded in broiler chickens following IV injection of $10 \mathrm{mg} / \mathrm{kg}$ b.w. The total clearance of TVN was $(1.17 \mathrm{~L} / \mathrm{h} / \mathrm{kg})$ indicating a relatively quicker clearance in broiler turkeys. Nearly equal clearance values $(1.498$ and $0.953 \mathrm{~L} / \mathrm{h} / \mathrm{kg}$ ) has been detected for TVN in turkeys and broiler chickens after IV injection (21) and (24), respectively. A larger value of TVN clearance $(4.37 \mathrm{~L} / \mathrm{h} / \mathrm{kg})$ was recorded in laying hens following IV injection of $10 \mathrm{mg} / \mathrm{kg}$ b.w. (22). In broiler chickens, higher clearance values after IV injection of $10 \mathrm{mg} / \mathrm{kg}$ b.w. of tylosin were 1.71 and $1.61 \mathrm{~L} / \mathrm{h} / \mathrm{kg}$ (18) and $5.3 \mathrm{~L} / \mathrm{h} / \mathrm{kg}(16)$.

Following PO administration, TVN showed rapid absorption from the alimentary tract of turkeys as indicated by short $\mathrm{t}_{1 / 2 \mathrm{ka}}(0.955 \mathrm{~h})$ and MAT $(2.31 \mathrm{~h})$ as well as small ka $(0.745 / \mathrm{h})$. Similarly, rapid absorption of TVN was recorded where the $\mathrm{t}_{1 / 2 \mathrm{ka}}$ and $\mathrm{ka}$ were $0.875 \mathrm{~h}, 0.799 / \mathrm{h}(24), 0.94 \mathrm{~h}$, and $0.69 / \mathrm{h}$ (23) in broiler chickens and the $t_{1 / 2 \mathrm{ka}}$ was $0.74 \mathrm{~h}$ in laying hens (22). Moreover, shorter $t_{1 / 2 k a}$ values of TVN after PO dosing of $20 \mathrm{mg} / \mathrm{kg}$ b.w. using a rigid $(0.471 \mathrm{~h})$ or a flexible $(0.175 \mathrm{~h})$ catheter were reported also in broiler chickens (31). Also, the rapid absorption of TVN tartrate after PO giving to broiler chicken was recorded (6). Shorter $t_{1 / 2 \mathrm{ka}}$ of tylosin tartrate $[0.48 \mathrm{~h},(18)],[0.19 \mathrm{~h}(25)$ and $0.3 \mathrm{~h}(26)]$ were also recorded in broiler chickens. The maximum plasma level $\left(\mathrm{C}_{\max }\right)$ of TVN after PO dosing to turkeys were $1.53 \mu \mathrm{g} / \mathrm{mL}$ and attained shortly $(2 \mathrm{~h})$ after administration. Additionally, the plasma concentration of TVN in the current study remained for $24 \mathrm{~h}$ higher than the MICs for TVN against several isolates of Mycoplasma gallisepticum (0.015-0.03 $\mu \mathrm{g} / \mathrm{mL})$ and Mycoplasma synoviae $(0.015 \mu \mathrm{g} / \mathrm{mL})$ isolated recently (Jan., 2017-Dec., 2018) from turkeys in Egypt (32) and TVN was found to be more effective than tilmicosin and tylosin in this study. Also, in another recent study (2014-2016), the MICs of TVN against 17 strains of Mycoplasma synoviae isolated from broiler turkeys originating from Central and Eastern Europe were $\leq 0.25 \mathrm{ug} / \mathrm{mL}$ (33). Nearly similar and different values of $\mathrm{C}_{\max }$ and $\mathrm{T}_{\max }$ of TVN in turkey and broiler chickens were recorded. In turkeys, the $\mathrm{C}_{\max }$ and $\mathrm{T}_{\max }$ of TVN were $0.637 \mu \mathrm{g} / \mathrm{mL}$ and $1.293 \mathrm{~h}(21)$. The $\mathrm{C}_{\max }$ of TVN in broiler chickens were 2.11 and $1.23 \mu \mathrm{g} / \mathrm{mL}$, attained at 2.03 and $1.72 \mathrm{~h} \mathrm{(23)} \mathrm{and} \mathrm{(24),} \mathrm{respectively,} \mathrm{and}$ that of laying hens (20 mg/kg b.w.) was $22 \mu \mathrm{g} / \mathrm{mL}$ achieved at $0.86 \mathrm{~h}$, respectively (22). Moreover, Cerda' et al. found in broiler chickens that the $\mathrm{C}_{\max }$ of TVN (20 mg/kg b.w.) using a rigid or a flexible catheter were 6.104 and $1.641 \mu \mathrm{g} / \mathrm{mL}$ and achieved at 1.202 and $0.571 \mathrm{~h}$, respectively (31). The $\mathrm{C}_{\max }$ of tylosin in broiler chickens was 1.2 (0.18 and 0.44$), 3.4$ and $4.85 \mu \mathrm{g} / \mathrm{mL}$ attained at $1.5(1.31$ and 1.33$), 1.08$ and $1.32 \mathrm{~h}$ $(16,18,25,26)$, respectively. Our data showed that, the oral bioavailability of TVN was moderate (53.3\%), higher than that of TVN in turkey [33.84\% (21)] and nearly similar to that of TVN in chickens which was $60.26,48.39$, and $63.83 \%$ $(22,24,34)$, respectively. However, in broiler chickens, the oral bioavailability of tylosin was from 35.4 to $40.6 \%$ (17), 13.74 to $27.0 \%(18)$, and $90.3 \%(25)$ and $89.2 \%$ (26). The differences in kinetic parameters between TVN and tylosin might be due to the differences in the chemical structure of both drugs (3). For anticipating the clinical efficacy of time-dependent antibacterial drugs, using the surrogate marker of the time free drug concentration in plasma is above the minimum inhibitory concentration $\mathrm{fT} \geq / \mathrm{MIC}$ (35), TVN would be a successful agent in turkeys for microorganisms with MIC $\leq$ $0.015-0.03 \mu \mathrm{g} / \mathrm{mL}$ after PO administration. Oral administration of $25 \mathrm{mg} / \mathrm{kg}$ b.w. of TVN every $24 \mathrm{~h}$ in broiler turkeys would be effective against several bacterial infections as chronic 
respiratory diseases caused by Mycoplasma gallisepticum and Mycoplasma synoviae.

In conclusion, administration of TVN $(25 \mathrm{mg} / \mathrm{kg}$ b.w. each $24 \mathrm{~h}$ ) might be highly effective for susceptible bacterial diseases in turkeys. However, further studies on tissue residues are necessary.

\section{DATA AVAILABILITY STATEMENT}

All datasets generated for this study are included in the manuscript/supplementary files.

\section{REFERENCES}

1. Guedes RMC, Franca SA, Machado GS, Blumer MA, Cruz ECD. Use of tylvalosin-medicated feed to control porcine proliferative enteropathy. Vet Rec. (2009) 165:342-5. doi: 10.1136/vr.165.12.342

2. Zhao Z, Tang X, Zhao X, Zhang M, Zhang W, Hou S, et al. Tylvalosin exhibits anti-inflammatory property and attenuates acute lung injury in different models possibly through suppression of NF- $\kappa \mathrm{B}$ activation. Biochem Pharmacol. (2014) 90:73-87. doi: 10.1016/j.bcp.2014.04.015

3. Stuart AD, Brown TDK, Imrie G, Tasker JB, Mockett AA. Intra-cellular accumulation and trans-epithelial transport of aivlosin, tylosin and tilmicosin. Pig J. (2007) 60:26-35.

4. Stuart AD, Brown TDK, Mockett APA. Tylvalosin, a macrolide antibiotic, inhibits the in vitro replication of European and American porcine reproductive and respiratory syndrome virus (PRRS) viruses. Pig J. (2008) 61:42-8

5. Cerda' RO, Giacoboni GI, Xavier JA, Sansalone PL, Landoni MF In vitro antibiotic susceptibility of field isolates of Mycoplasma synoviae in Argentina. Avian Dis. (2002) 46:215-8. doi: 10.1637/00052086(2002)046[0215:IVASOF]2.0.CO;2

6. Giguère S. Macrolides, azalides, and ketolides. In: Giguère S, Prescott JF, Dowling PM, editors, Antimicrobial Therapy in Veterinary Medicine, 5th ed. Wiley-Blackwell (2013). p. 211-31.

7. Forrester CA, Bradbury JM, Dare CM, Domangue RJ, Windsor H, Tasker JB, et al. Mycoplasma gallisepticum in pheasants and the efficacy of tylvalosin to treat the disease. Avian Pathol. (2011) 40:581-6. doi: 10.1080/03079457.2011.618822

8. Canning P, Bates J, Hammen K, Coetzee J, Wulf L, Rajewski S, et al. Concentrations of tylvalosin and 3-O-acetyltylosin attained in the synovial fluid of swine after administration by oral gavage at 50 and $5 \mathrm{mg} / \mathrm{kg}$. J Vet Pharmacol Ther. (2016) 39:621-4. doi: 10.1111/jvp.12309

9. Craig W, Suh B. Protein binding and the antimicrobial effects: methods for the determination of protein binding. In: Lorian V, editor. Antibiotics in Laboratory Medicine, 3rd ed. Baltimore, MD: Williams \& Wilkins (1991). p. 367-402.

10. Elbadawy M, Sakiyama T, Abohatab R, Sasaki K, Shimoda M. Oral pharmacokinetics of the acidic drugs, diclofenac and sulfamonomethoxine in male Shiba goats. J Vet Med Sci. (2015) 77:21-6. doi: 10.1292/jvms.14-0261

11. Elbadawy M, Sasaki K, Miyazaki Y, Aboubakr M, Khalil WF, Shimoda M. Oral pharmacokinetics of acetaminophen to evaluate gastric emptying profiles of Shiba goats. J Vet Med Sci. (2015) 77:1331-4. doi: 10.1292/jvms.15-0104

12. Elbadawy M, Ishihara Y, Aboubakr M, Sasaki K, Shimoda M. Oral absorption profiles of sulfonamides in Shiba goats: a comparison among sulfadimidine, sulfadiazine and sulfanilamide. J Vet Med Sci. (2016) 78:10259. doi: 10.1292/jvms.15-0601

13. Yamaoka K, Tanigawara Y, Nakagawa T, Uno T. A. Pharmacokinetic analysis program (multi) for microcomputer. J Pharmacobiodyn. (1981) 4:879-85. doi: $10.1248 / \mathrm{bpb} 1978.4 .879$

14. Gibaldi M, Perrier D. Noncompartmental analysis based on statistical moment theory. In: Gibaldi $M$, Perrier D, editors.

\section{ETHICS STATEMENT}

The experimental protocol was approved ethically by the local Ethical Committee of the Faculty of Veterinary Medicine, Benha University, Egypt.

\section{AUTHOR CONTRIBUTIONS}

ME contributed to the idea, design, performing the experiment, and writing the manuscript. MA contributed to pharmacokinetic analysis and revising the manuscript. AA performed the calculations, English check and grammars, and validation.

Pharmacokinetics, 2nd ed. New York, NY: Informa Healthcare (1982). p. 409-17.

15. Locke D, Bush M, Carpenter JW. Pharmacokinetics and tissue concentrations of tylosin in selected avian species. Am J Vet Res. (1982) 43:1807-10.

16. Kowalski C, Rolinski Z, Zan R, Wawron W. Pharmacokinetics of tylosin in broiler chickens. Pol J Vet Sci. (2002) 5:127-30.

17. Abu-Basha EA, Al-Shunnaq AF, Gehring R. Comparative pharmacokinetics and bioavailability of two tylosin formulations in chickens after oral administration. J Hell Vet Med Soc. (2012) 63:159-66. doi: 10.12681/jhvms.15431

18. Ji LW, Dong LL, Ji H, Feng XW, Li D, Ding RL, et al. Comparative pharmacokinetics and bioavailability of tylosin tartrate and tylosin phosphate after a single oral and i.v. administration in chickens. J Vet Pharmacol Ther. (2014) 37:312-5. doi: 10.1111/jvp.12092

19. Elbadawy M, Aboubakr M. Pharmacokinetics, tissue residues of tilmicosin phosphate (tilmicor-al ${ }^{\circledR}$ ) and it's in vitro and in vivo evaluation for the control of Mycoplasma gallisepticum infection in broiler chickens. Int J Pharmaco Toxicol. (2017) 5:11-6. doi: 10.14419/ijpt.v5i1.7084

20. Fricke JA, Clark CR, Boison JO, Chirino-Trejo M, Inglis TE, Dowling PM. Pharmacokinetics and tissue depletion of tilmicosin in turkeys. $J$ Vet Pharmacol Ther. (2008) 31:591-4. doi: 10.1111/j.1365-2885.2008.00 985.x

21. Radi AM. Pharmacokinetic and bioavailability of tylvalosin after oral, intramuscular and intravenous administration in turkeys. Int J Pharm Pharm Sci. (2016) 8:140-4.

22. Liu LN. Pharmacokinetics of acetylisovaleryltylosin tartrate in laying hens [Dissertation/master's thesis]. Department of Basic Veterinary Sciences, College of Veterinary Medicine, Huazhong Agricultural University, Huazhong, China.

23. Abo El-Ela FI, El-Banna HA, El-Deen MB, El-Gendy AA, Tohamy MA. Pharmacokinetics of tylvalosin alone or in combination with Vitamin $\mathrm{E}$ in broiler chickens. Asian $J$ Anim Vet Adv. (2015) 10:556-66. doi: 10.3923/ajava.2015.556 .566

24. Salman AH, Youssef SAH, Ramadan A, Soliman AM. Pharmacokinetics of tylvalosin in healthy and experimentally Mycoplasma gallisepticum infected broiler chickens. Int J PharmTech Res. (2016) 9:72-80.

25. Soliman AM, Sedeik M. Pharmacokinetics and tissue residues of tylosin in broiler chickens. Pharmacol Pharm. (2016) 7:36-42. doi: $10.4236 / p p .2016 .71006$

26. Aboubakr M, Elbadawy M. Pharmacokinetics, tissue residues and efficacy of D-Tylo50/25 ${ }^{\circledR}$ (tylosin-doxycycline combination) in broiler chickens. Int J Basic Clin Pharmacol. (2017) 6:383-8. doi: 10.18203/2319-2003.ijbcp20170334

27. AwadAllah H, Awidat S, El-Mahmoudy A. Pharmacokinetics of clarithromycin after single intravenous and intracrop bolus administrations to broiler chickens. Int J Pharmacol Toxicol. (2016) 4:12-8. doi: 10.14419/ijpt.v4i1.5846

28. Goudah A, Abo El Sooud K, Abd El-Aty AM. Pharmacokinetics and tissue residue profiles of erythromycin in broiler chickens after 
different routes of administration. Dtsch Tierarztl Wochenschr. (2004) 111:162-5.

29. Papich MG. Chloramphenicol and derivatives, macrolides, lincosamides, and miscellaneous antimicrobials. In: Riviere JE, Papich MJ, editors. Veterinary Pharmacology and Therapeutics, 10th ed. Hoboken, NJ: John Wiley \& Sons, Inc. (2018). p. 912-24.

30. Baggot JD, Gingerich DA. Pharmacokinetic interpretation of erythromycin and tylosin activity in serum after intravenous administration of a single dose to cows. Res Vet Sci. (1976) 21:318-23. doi: 10.1016/S0034-5288(18)33344-7

31. Cerda' RO, Petruccelli M, Piscopo M, Origlia J, Landoni M. Impact of the type of catheter on the absorption of tylvalosin (acetylvaleryltylosin) administered orally to broiler chickens. J Vet Pharmacol Ther. (2010) 33:2023. doi: 10.1111/j.1365-2885.2009.01103.x

32. El-Hamid MIA, Awad NFS, Abo-Shama UH, Yousreya MH, Abdel-Rahman MA, Hetta HF, et al. In vitro evaluation of various antimicrobials against field Mycoplasma gallisepticum and Mycoplasma synoviae isolates in Egypt. bioRxiv. (2019). doi: 10.1101/726000

33. Kreizinger Z, Grózner D, Sulyok KM, Nilsson K, Hrivnák V, Benčina D, et al. Antibiotic susceptibility profiles of Mycoplasma synoviae strains originating from Central and Eastern Europe. BMC Vet Res. (2017) 13:342. doi: 10.1186/s12917-017-1266-2
34. Cerda' RO, Petruccelli MA, Piscopo M, Herrero M, Landoni MF. Effect of the grapefruit juice on the oral absorption of acetylisovaleryltylosin tartrate (aivlosin) in 2 weeks old chickens. Session I: pharmacokinetics. J Vet Pharmacol Ther. (2006) 29:239-79. doi: 10.1111/j.1365-2885.2006. 00767.x

35. Barbour A, Scaglione F, Derendorf H. Class-dependent relevance of tissue distribution in the interpretation of anti-infective pharmacokinetic/pharmacodynamic indices. Int $J$ Antimicrob Agents. (2010) 35:431-8. doi: 10.1016/j.ijantimicag.2010.01.023

Conflict of Interest: The authors declare that the research was conducted in the absence of any commercial or financial relationships that could be construed as a potential conflict of interest.

Copyright (c) 2019 Elbadawy, Aboubakr and Abugomaa. This is an open-access article distributed under the terms of the Creative Commons Attribution License (CC $B Y)$. The use, distribution or reproduction in other forums is permitted, provided the original author(s) and the copyright owner(s) are credited and that the original publication in this journal is cited, in accordance with accepted academic practice. No use, distribution or reproduction is permitted which does not comply with these terms. 